\section{Influence of Gel Additives on Nitrate, Ammonium, and Water Retention and Tomato Growth in a Soilless Medium}

\author{
Wlodzimierz Bres' ${ }^{1}$ and Leslie A. Weston \\ Department of Horticulture and Landscape Architecture, University of \\ Kentucky, Lexington, KY 40546-0091
}

Additional index words. fertilizer, hydrogel, hydrophilic polymers, Lycopersicon esculentum, nutrients, polyacrylamide copolymers, water-holding capacity

\begin{abstract}
Experiments were conducted to evaluate the effect of incorporated hydrogel amendments to a soilless growth medium on ammonium, nitrate, and water retention and tomato (Lycopersicon esculentum Mill.) seedling growth. HydroSource and Agri-gel were incorporated into a 1 peat : 1 perlite : 1 vermiculite soilless medium at rates of 1,2 , or 3 $\mathrm{g} \cdot$ liter $^{-1}$ with $0.88 \mathrm{~g}$ of ammonium nitrate fertilizer. Water retention by the growth medium increased linearly with gel application; HydroSource generally was more effective than Agri-gel. Between $90 \%$ and $96 \%$ of the applied nitrate-N was recovered in the resulting leachate of the gel-amended media, while $33 \%$ to $55 \%$ of the ammonium-N was recovered. Nitrate-N and ammonium-N retention was higher when $3 \mathrm{~g} \cdot \mathrm{liter}^{-1}$ of either gel was added to the growth medium than when lower amounts or no gel was added. Gel amendment did not affect tomato seedling growth. Total foliar $\mathbf{N}$ concentration in tomato leaves was significantly higher in the HydroSource treatments than in the control or Agri-gel treatments.
\end{abstract}

Higher plants effectively use only a small percentage of available water. Techniques that would enable plants to have greater access to water are worthy of further study. Amending plant growth media with hydrophilic polymers (soil conditioners) has 1) increased water retention (Johnson, 1984; Quinn, 1990), 2) reduced watering frequency (Still, 1976; Taylor and Halfacre, 1986),3) improved soil tex-

\footnotetext{
Received for publication 7 Dec. 1992. Accepted for publication 8 June 1993. The investigation reported in this paper (91-10-63) is in connection with a project of the Kentucky Agricultural Experiment Station and is published with the approval of the director. The cost of publishing this paper was defrayed in part by the payment of page charges. Under postal regulations, this paper therefore must be hereby marked advertisement solely to indicate this fact.

'Present address: Dept. of Horticultural Plant Nutrition, Univ. of Agriculture, Dabrowskiego 169, Poznan 60-594, Poland.
}

ture (Wallace and Wallace, 1986b, 1986c), 4) increased water infiltration (Mitchell, 1986; Wallace and Wallace, 1986c), 5) reduced erosion and water runoff (Wallace and Wallace, 1986d), and 6) increased germination and improved early growth of plants (Cook and Nelson, 1986; Wallace and Wallace, 1986a, 1986b). However, other studies showed that water-soluble polymers did not affect plant growth (Conover and Poole, 1976; Ingram and Yeager, 1987; Wang, 1989) or irrigation frequency (Tu et al., 1985; Wang and Boogher, 1987). This difference may be related to the gel type and amount applied. High gel incorporation rates in the growth medium have reduced plant growth in some cases (Taylor and Halfacre, 1986), but potential for phytotoxicity remains unclear (Still, 1976; Wallace et al., 1986).

Hydrophilic polymers used in commercial production include starch acrylate, polyvinylalcohol, and polyacrylamide copolymers.
Some polymers can hold up to 1500 times their weight in pure water (Johnson, 1984). Recently, fertilizers have been mixed with these polymers to increase water and fertilizer availability. However, adding fertilizer can reduce gel hydration significantly (Bowman et al., 1990; Foster and Keever, 1990).

The objectives of this study were to determine the effect of rate and type of two commonly available cross-linked polyacrylamide gels on 1) nitrate-N, ammonium- $\mathrm{N}$, and water retention in a soilless plant growth medium and 2) tomato seedling growth and $\mathrm{N}$ concentration in seedling leaf tissue.

Two gels, Agri-gel (Amereq, Congres, N.Y.) and HydroSource (Western Polyacrylamide, Castle Rock, Colo.), were evaluated in laboratory experiments conducted in 1990 at the Univ. of Kentucky, Lexington, to assess the physical characteristics of gel- and fertilizer-amended growth media. Both gels are advertised as water-absorbing polymers that enhance seed germination and emergence uniformity. The growth medium was a mixture (by volume) of 1 sphagnum peat (Tourbieres Lambert Peat Moss, RiviereQuelle, Quebec) : 1 horticultural perlite (ChemRock Corp., Nashville): 1 vermiculite (Grace Horticultural Products, W.R. Grace and Co., Cambridge, Mass.). Ammonium nitrate fertilizer was dissolved in distilled water and mixed with dry gels in the following ratios (in grams) of ammonium nitrate fertilizer : water : gel-Rate 1, 0.88:20:1 g; Rate 2, 0.88:40:2 g; Rate 3,0.88:60:3 g.

Nitrogen level (154 mg $\mathrm{NH}_{4}-\mathrm{N}, 154 \mathrm{mg}$ $\mathrm{NO}_{3}-\mathrm{N}$ ) was kept constant among treatments, and gel and water addition varied among treatments. Thus, gel consistency was uniform among treatments. After allowing for thorough solution absorbance, gel mixtures were mixed thoroughly with $1000 \mathrm{~cm}^{3}$ of soil less medium. The control treatment contained fertilizer dissolved in water but no gel. Media were placed in polyvinylchloride (PVC) columns $50 \mathrm{~cm}$ high and $4.4 \mathrm{~cm}$ in diameter. The bottom of the column was covered with four layers of cheesecloth. Separator funnels containing $600 \mathrm{ml}$ distilled water were placed above each column. Water was allowed to flow into the column at a rate of $60 \mathrm{ml} \cdot \mathrm{min}^{-1}$ for $10 \mathrm{~min}$, and the column leachate was collected 
into glass flasks to separate each 100 -ml fraction of leachate. Leachate solutions were collected for $4 \mathrm{~h}$. Total leachate volume collected varied with treatment. The amounts of $\mathrm{NH}_{4}-\mathrm{N}$ and $\mathrm{NO}_{3}-\mathrm{N}$ in each fraction were determined using the automated calorimetric phenate method (Kopp and McKee, 1978).

The physical effect of gel rate and type on medium water retention was determined in additional experiments. Growth media were prepared as above. The soilless medium (400 $\mathrm{cm}^{3}$ ) was mixed with $0,0.4,0.8$, or $1.2 \mathrm{~g}$ of the gels, as previously described. PVC columns $20 \mathrm{~cm}$ high and $4.4 \mathrm{~cm}$ in diameter $\left(304 \mathrm{~cm}^{3}\right)$ were packed firmly with $300 \mathrm{~cm}^{3}$ of each medium. The columns containing media were placed in distilled water to a depth of $6.5 \mathrm{~cm}$. Capillary rise was sufficient to ensure that soil at the top of the column was moistened so that water retention could be determined. After being removed from the water, the columns were allowed to drain for $15 \mathrm{~min}$ to remove free water. Water retention was calculated based on the weights of dry and moistened media measured at 0 and $48 \mathrm{~h}$ (Hanks and Ashcroft, 1980).

Treatments in both experiments were replicated three times and arranged factorially in randomized complete-block designs. Both experiments were performed twice, and data were combined since the results of both runs were similar. Combined data were subjected to analysis of variance. Orthogonal contrasts were performed where appropriate. Means were separated by Fisher's protected least significant difference (LSD) $(P \leq 0.05)$.

A third experiment was conducted to determine the effect of gels on plant growth and foliar $\mathrm{N}$ concentration. Growth media were prepared as in the first experiment. Superphosphate $\left(1.25 \mathrm{~g} \cdot\right.$ liter $\left.^{-1}\right)$, potassium sulfate $(0.8$ $\left.\mathrm{g} \cdot \mathrm{liter}^{-1}\right)$, and dolomite $\left(6.5 \mathrm{~g} \cdot \mathrm{liter}^{-1}\right)$ were incorporated into the media along with the following micronutrients (in milligrams per liter): $5 \mathrm{~B}\left(\mathrm{H}_{3} \mathrm{BO}_{3}\right), 4 \mathrm{Mn}\left(\mathrm{MnCl}_{2}\right), 2.2 \mathrm{Zn}$ $\left(\mathrm{ZnSO}_{4} \cdot 7 \mathrm{H}_{2} \mathrm{O}\right), 0.5 \mathrm{Cu}\left(\mathrm{CuSO}_{4} \cdot 5 \mathrm{H}_{2} \mathrm{O}\right), 0.5 \mathrm{Mo}$ $\left(\mathrm{H}_{2} \mathrm{MoO}_{4}\right), 25 \mathrm{Fe}$ (sequestrene $\left.\mathrm{Fe} 330\right)$. Aqueous solutions of 20,40 , and $60 \mathrm{ml}$ containing $0.88 \mathrm{~g}$ of ammonium nitrate fertilizer were combined with 1,2, and $3 \mathrm{~g}$ of each gel, respectively. The gels absorbed aqueous ammonium nitrate solution as described for the first experiment and were added to $1000 \mathrm{~cm}^{3}$ of medium. The control treatment contained no gel. Individual, 4-week-old 'Mountain Pride' tomato seedlings were planted into 1-liter plastic pots containing the above mixtures. Plants were placed in a growth chamber maintained at $26 \mathrm{C}$ day $/ 24 \mathrm{C}$ night with $85 \% \pm 2 \%$ relative humidity and 14-h days, 10-h nights, and an average photosynthetic photon flux density of $500 \mathrm{~mol} \cdot \mathrm{m}^{-2} \cdot \mathrm{s}^{-1}$. Treatments were replicated six times and arranged factorially in a randomized complete-block design. Tomato plants were watered every 2 days with distilled water to maintain a similar moisture level in each treatment, as estimated by individual weights of pots. Leaf samples (two lowest true leaves) were collected 2 and 4 weeks after the experiment began. The samples were oven-dried at $50 \mathrm{C}$ and ground in a Wiley mill, and total $\mathrm{N}$
(microKjeldahl method) (Eastin, 1978) was determined. Height and fresh weight of tomato plants were measured after 4 weeks at the end of the experiment. The experiments were repeated and combined data were subjected to appropriate analysis of variance for the factorial experiments. Orthogonal contrasts were performed where appropriate. Means were separated by Fisher's protected LSD .

The volume of leachate collected from each mixture, an indirect measure of the ability of the growth media to retain water, was affected significantly by gel type and quantity (Table 1). The gel $\times$ rate interaction was significant, with Agri-gel at $3 \mathrm{~g}$ retaining significantly more water (i.e., allowing less leachate) than HydroSource at this rate. The gel-amended media held $38 \%$ (1 g, HydroSource) to $74 \%$ (3 $\mathrm{g}$, Agri-gel) of the water applied. Gels improved water retention some when 1 or $2 \mathrm{~g}$ was incorporated, but retention was most enhanced at $3 \mathrm{~g}$ with either gel compared to the control. Polyacrylamide gels like HydroSource and Agri-gel have been reported to absorb 400 to 500 times their density in deionized water (Foster and Keever, 1990).

Based on the chemical analysis of leachate solutions, the amount of $\mathrm{NO}_{3}-\mathrm{N}$ leached from the media varied with the amount of gel incorporated, with slightly less leaching occurring at the highest gel incorporation rate (Table 1). Gel type $\times$ rate interactions did not influence $\mathrm{NO}_{3}-\mathrm{N}$ leaching. HydroSource improved nitrate retention in the medium slightly, whereas Agri-gel had no effect compared to the control. Overall, $90 \%$ to $96 \%$ of the $\mathrm{NO}_{3}-\mathrm{N}$ applied was recovered in the leachate solutions, a result indicating that only $4 \%$ to $10 \%$ of $\mathrm{NO}_{3}-\mathrm{N}$ was potentially retained by the medium after leaching. In all experiments, $>50 \%$

Table 1. Effect of incorporating two gels at three rates on water, $\mathrm{NH}_{4}-\mathrm{N}, \mathrm{NO}_{3}-\mathrm{N}$, and water retention in a soilless medium.

\begin{tabular}{|c|c|c|c|c|c|c|}
\hline $\begin{array}{l}\text { Hydrogel } \\
\text { and amount } \\
\text { (g) }\end{array}$ & $\begin{array}{c}\text { Total } \\
\text { vol } \\
\text { of leachate } \\
(\mathrm{ml})\end{array}$ & $\begin{array}{c}\mathrm{NO}_{3}-\mathrm{N} \\
\text { leached } \\
\text { (mg) }\end{array}$ & $\begin{array}{c}\mathrm{NO}_{3}-\mathrm{N} \\
\text { leachate } \\
\text { recovery } \\
(\%)\end{array}$ & $\begin{array}{c}\mathrm{NH}_{4}-\mathrm{N} \\
\text { leached } \\
(\mathrm{mg}) \\
\end{array}$ & $\begin{array}{c}\mathrm{NH}_{4}-\mathrm{N} \\
\text { leachate } \\
\text { recovery } \\
(\%)\end{array}$ & $\begin{array}{c}\text { Water } \\
\text { retention } \\
(\%)\end{array}$ \\
\hline None (control) & 423 & 148 & 96 & 85.3 & 55 & 305 \\
\hline \multicolumn{7}{|l|}{ HydroSource } \\
\hline 1 & 362 & 142 & 92 & 79.2 & 51 & 360 \\
\hline 2 & 359 & 144 & 94 & 64.0 & 42 & 391 \\
\hline 3 & 305 & 139 & 90 & 51.8 & 34 & 409 \\
\hline \multicolumn{7}{|l|}{ Agri-gel } \\
\hline 1 & 357 & 148 & 96 & 81.2 & 53 & 332 \\
\hline 2 & 350 & 147 & 95 & 72.0 & 47 & 363 \\
\hline 3 & 148 & 138 & 90 & 50.8 & 33 & 392 \\
\hline $\mathrm{LSD}_{(0.05)}$ & 12.8 & 8.5 & & 5.0 & & 24.2 \\
\hline \multicolumn{7}{|c|}{ Factorial analysis } \\
\hline Gel (G) main effect & ** & * & * & ** & & \\
\hline \multicolumn{7}{|l|}{ Rate (R) main effect } \\
\hline Linear & NS & NS & ** & ** & & \\
\hline Quadratic & ** & ** & * & NS & & \\
\hline$G \times R$ interaction & ** & NS & * & NS & & \\
\hline \multicolumn{7}{|c|}{ Orthogonal contrasts } \\
\hline Control vs. HydroSource & ** & $*$ & ** & ** & & \\
\hline Control vs. Agri-gel & ** & NS & ** & ** & & \\
\hline HydroSource vs. Agri-gel & ** & NS & * & ** & & \\
\hline
\end{tabular}

${ }^{2}$ Based on $600 \mathrm{ml}$ water applied.

'Based on $154 \mathrm{mg} \mathrm{NH}_{4}-\mathrm{N}$ and $154 \mathrm{mg} \mathrm{NO}_{3}-\mathrm{N}$ applied.

'Percent water retention based on comparison with the dry weight of the artificial growth medium. ss,,$* *$ Nonsignificant or significant at $P \leq 0.05$ or 0.01 , respectively. of leached $\mathrm{NO}_{3}-\mathrm{N}$ was found in the first $100 \mathrm{ml}$ of leachate (data not presented).

Retention of $\mathrm{NH}_{4}-\mathrm{N}$ also was affected by the type and rate of gel incorporation. Gel $x$ rate interactions were significant, with HydroSource retaining slightly more (i.e., leaching less) ammonium at $2 \mathrm{~g}$ than Agri-gel (Table 1). Ammonium retention increased with increasing gel application with both gel types. From $33 \%$ to $55 \%$ of $\mathrm{NH}_{4}-\mathrm{N}$ added to the gels was recovered in the leachates, a result indicating that $45 \%$ to $67 \%$ of $\mathrm{NH}_{4}-\mathrm{N}$ was potentially retained in the media. Not surprisingly, $\mathrm{NH}_{4}-\mathrm{N}$ leaching was less rapid than $\mathrm{NO}_{3}-\mathrm{N}$ leaching. The control medium (without gel) lost the greatest quantity of both $\mathrm{N}$ forms. that, regardless of the gel incorporation rate, $>85 \%$ of the total ammonium was retained in the amended medium, whereas nitrate retention was minimal in any medium. The peatbased growth medium likely adsorbs part of the $\mathrm{NH}_{4}-\mathrm{N}$. In addition, the gel may adsorb $\mathrm{NH}_{4}-\mathrm{N}$. However, the cation-exchange capacity of both gels is thought to be limited (Fernando Erazo, Amereq, personal communication).

The type and rate of gel incorporation increased water retention of the growth medium by up to $25 \%$ (Table 1). Adding HydroSource or Agri-gel increased long-term water retention (after $48 \mathrm{~h}$ ) at 1 and $2 \mathrm{~g}$ of gel. No differences in water retention were observed between the two gel types at the highest gel incorporation rate $(3 \mathrm{~g})$. Adding gel increased water retention volume of the media regardless of the type of gel used, relative to the medium without gel.

Other investigators have obtained similar results. Wang and Gregg (1990) reported that medium bulk density, total water retention, Henderson and Hensley (1985) also found 
and water retention per unit volume of medium were increased by hydrogel incorporation. Noncapillary porosity, measured at container capacity in a medium amended with Micromax (micronutrient fertilizer), progressively decreased as the amount of hydrogel increased. Bowman et al. (1990) also found that adding gel improved the medium's physical properties. According to Taylor and Halfacre (1986), hydrophilic polymers can be used to decrease moisture requirements, but water retention can be diminished by the destruction of the polymer lattice by adding divalent cations with fertilizer amendment. Despite the fact that ammonium nitrate was added to the two gel treatments, water retention in our experiments increased with increasing amounts of gel.

In the third experiment, tomato seedlings were grown with various gel amendments in the presence of similar water supplies. Removing the water supply as a confounding factor allowed us to assess the effect of gel rate and type on seedling growth and foliar $\mathrm{N}$ concentration. This procedure was important, since adding certain gels at higher rates reduced overall plant growth (Taylor and Halfacre, 1986). Fresh and dry weights of tomato seedlings were not affected by adding hydrogels to the growth media (data not presented). Similar results were obtained by Wang (1989) in experiments with tropical ornamental plants. However, Wallace and Wallace (1986d) found that using gel amendments increased dry weights of tomato, cotton (Gossypium hirsutum L.), and lettuce (Lactuca sativa L.) seedlings. Wang and Boogher (1987) reported that gel amendment did not affect the fresh weight of Boston ferns (Nephrolepis exaltata L. Schott) but increased the size of 'Variegatum' spider plants [Chlorophytum comosum (Thunb.) Jacques]. These reported increases in plant growth may be related to increased water availability associated with gel addition. Adding gel reduced tomato seedling height slightly over the short duration of our experiment; treated seedlings appeared more compact (control, $18.0 \mathrm{~cm}$, HydroSource, $15.3 \mathrm{~cm}$; Agri-gel, $16.7 \mathrm{~cm}$ ). However, total N concentration in tomato leaves also was influenced by gel addition. Foliar $\mathrm{N}$ concentration was significantly higher in the plants from the HydroSource treatments than in those from the Agri-gel or control treatments 2 and 4 weeks after the experiment began (Table 2). The effect of gel rate was observed only at the first sample collection (2 weeks). According to Taylor and Halfacre (1986), adding gel to the growth medium also increased total $\mathrm{N}$ concentration in Ligustrum lucidum Ait. leaves.

Many contradictory opinions regarding the beneficial influence of gels on media properties and plant growth are associated with the different types of gels and media. Adding HydroSource or Agri-gel to the plant growth medium increased water retention. Nitrate re-
Table 2. Effect of incorporating two gels at three rates on height and total foliar $\mathrm{N}$ concentration (percentage, dry weight basis) in the two lowest true leaves of tomato seedlings grown in a soilless medium. ${ }^{2}$

\begin{tabular}{|c|c|c|c|}
\hline \multirow{2}{*}{$\begin{array}{l}\text { Hydrogel } \\
\text { and amount }(\mathrm{g})\end{array}$} & \multirow{2}{*}{$\begin{array}{c}\mathrm{Ht} \\
(\mathrm{cm})\end{array}$} & \multicolumn{2}{|c|}{$\begin{array}{c}\text { Total N } \\
\text { concn }(\%)\end{array}$} \\
\hline & & 2 wks & $4 \mathrm{wks}$ \\
\hline None (control) & 18.0 & 4.38 & 3.17 \\
\hline \multicolumn{4}{|l|}{ HydroSource } \\
\hline 1 & 15.3 & 5.53 & 3.44 \\
\hline 2 & 15.7 & 5.22 & 3.35 \\
\hline 3 & 15.0 & 4.77 & 3.43 \\
\hline \multicolumn{4}{|l|}{ Agri-gel } \\
\hline 1 & 18.0 & 3.53 & 3.19 \\
\hline 2 & 17.3 & 4.56 & 3.09 \\
\hline 3 & 14.7 & 4.27 & 3.10 \\
\hline $\operatorname{LSD}_{(0.05)}$ & NS & 0.15 & 0.19 \\
\hline \multicolumn{4}{|c|}{ Factorial analysis } \\
\hline Gel (G) main effect & NS & ** & $* *$ \\
\hline \multicolumn{4}{|l|}{ Rate $(\mathrm{R})$ main effect } \\
\hline Linear & NS & NS & NS \\
\hline Quadratic & NS & $* *$ & NS \\
\hline $\mathbf{G} \times \mathbf{R}$ interaction & NS & $* *$ & NS \\
\hline \multicolumn{4}{|c|}{ Orthogonal contrasts } \\
\hline Control vs. HydroSource & $*$ & $* *$ & * \\
\hline Control vs. Agri-gel & * & NS & NS \\
\hline HydroSource vs. Agri-gel & * & $* *$ & * \\
\hline
\end{tabular}

${ }^{\text {zTomato seedling leaves were collected for nutrient }}$ analysis 2 and 4 weeks after the experiment began, and heights were measured at 4 weeks.

ss,",**Nonsignificant or significant at $P \leq 0.05$ or 0.01 , respectively.

tention was very low, regardless of the gel type investigated, whereas ammonium retention increased by adding gel. This difference may be related to the negative charge potential or the cation-exchange capacity of gel polymers. Gel incorporation did not affect the growth of tomato seedlings strongly over the short duration of these experiments under conditions in which water was not a limiting factor, although total $\mathrm{N}$ concentration in tomato leaves was influenced by gel addition. Based on the results obtained, $2 \mathrm{~g}$ HydroSource/liter artificial growth medium may be used to improve water and ammonium retention in the growth medium we used. Additional studies are required to determine whether the increased water or ammonium retention observed with gel addition may result in enhanced seedling growth under more stressful growth conditions.

\section{Literature Cited}

Bowman, D.C., R.Y. Evans, and J.L. Paul. 1990. Fertilizer salts reduce hydration of polyacrylamide gels and affect physical properties of gel-amended container media. J. Amer. Soc. Hort. Sci. 115:382-386.

Conover, C.A. and W. Poole. 1976. Influence of Viterra hydrogel on growth and control of wilting of 3 foliage plant species. Fla. Foliage Grower 13:332-333

Cook, D.F. and S.D. Nelson. 1986. Effect of polyacrylamide on seedling emergence incrust-forming soils. Soil Sci. 141:328-333.
Eastin, E.F. 1978. Total nitrogen determination for plant material containing nitrate. Anal. Biochem. 85:591-594

Foster, W.J. and G.J. Keever. 1990. Water absorption of hydrophilic polymers (hydrogels) reduced by media amendments. J. Environ. Hort. 8:113-114

Hanks, R.J. and G.L. Ashcroft. 1980. Applied soil physics. Springer-Verlag, New York. p. 4.

Henderson, J.C. and D.L. Hensley. 1985. Ammonium and nitrate retention by a hydrophilic gel. HortScience 20:667-668.

Ingram, D.L. and T.H. Yeager. 1987. Effects of irrigation frequency and a water-absorbing polymer amendment on Ligustrum growth and moisture retention by a container medium. J. Environ. Hort. 5:19-21.

Johnson, M.S. 1984. Effect of soluble salts on water absorption by gel-forming soil conditioners. J. Sci. Food Agr. 35: 1063-1066.

Kopp, J.F. and G.D. McKee. 1978. Methods for chemical analysis of water and wastes. 1. Nitrogen-Method 350. Environmental Protection Agency, Environmental Monitoring and Support Lab., Cincinnati. p. 168.

Mitchell, A.R. 1986. Polyacrylamide application in irrigation water to increase infiltration. Soil Sci. 141:353-358

Quinn, J.L. 1990. Superabsorbent hydrogel use in landscaping turf establishment, nurseries, interiorscaping and agriculture. Proc. Natl. Agr. Plastics Assn. p. 122-128.

Still, S.M. 1976. Growth of 'Sunny Mandalay' chrysanthemums in hardwood-bark-amended media as affected by insolubilized polyethylene oxide). HortScience 11:483-484.

Taylor, K.C. and R.G. Halfacre. 1986. The effect of hydrophilic polymer on media water retention and nutrient availability to Ligustrum lucidum. HortScience 21:1159-1 160.

Tu, Z.P., A.M. Armitage, and H.M. Vines. 1985 Influence of an antitranspirant and a hydrogel on net photosynthesis and water loss of cineraria during water stress. HortScience 20:386-388.

Wallace, A. and G.A. Wallace. 1986a. Effects of soil conditioners on emergence and growth of tomato, cotton, and lettuce seedlings. Soil Sci. 141:313-316

Wallace, A. and G.A. Wallace. 1986b. Effect of polymeric soil conditioners on emergence of tomato seedlings. Soil Sci. 141:321-323.

Wallace, A. and G.A. Wallace. 1986c. Effect of very low rates of synthetic soil conditioners on soils. Soil Sci. 141:324-327.

Wallace, A., G.A. Wallace, and A.M. Abouzamzam. 1986. Effects of excess levels of a polymer as a soil conditioner on yields and mineral nutrition of plants. Soil Sci. 141:377-380.

Wallace, G.A. and A. Wallace. 1986d. Control of soil erosion by polymeric soil conditioners. Soil Sci. 141:363-367.

Wang, Y. 1989. Medium and hydrogel affect production and wilting of tropical ornamental plants. HortScience 24:941-944.

Wang, Y. and C.A. Boogher. 1987. Effect of a medium-incorporated hydrogel on plant growth and water use of two foliage species. J. Environ. Host. 5:125-127.

Wang, Y. and L.L. Gregg. 1990. Hydrophilic polymers-Their response to soil amendments and effect on properties of a soilless potting mix. J. Amer. Soc. Hort. Sci. 115:943-946. 